\title{
A Seroepidemiological Investigation of Corynebacterium Pseudotuberculosis Infection in Sheep Flocks in Southern Norway
}

Corynebacterium pseudotuberculosis causes caseous lymphadenitis, a disease primarily affecting sheep and goats which occurs as a chronic infection characterized by suppurative lymphadenitis (Lovell 1959, Marsh 1965, Jubb \& Kennedy 1970, Ayers 1977, Addo \& Eid 1978). The disease has an insidious nature and a high prevalence, resulting in large economic losses due to condemnation of carcasses and organs at slaughter (Turner 1973).

In Norway, caseous lymphadenitis is common in goat herds (Holstad 1986a). Information regarding the occurrence of infection in Norwegian sheep flocks is, however, lacking.

The purpose of the present work was to obtain information concerning $C$ pseudotuberculosis infection in sheep flocks in southern Norway.

Serum samples from 10 precolostral lambs, 256 six-month old lambs and 764 adult sheep aged 1-9 years, from altogether 30 flocks, were examined by the hemolysis inhibition test (HIT). The test was performed in a similar way as described by Holstad (1986b). Antibody titres were expressed as $\log _{10}$ to be reciprocal value of the last serum dilution that inhibited hemolysis. Titre values $(T) \geq 0.6$ were regarded as positives.

Table 1 presents the results of the serological examination. Out of 1030 animals examined, 89 (8.6 \%) were seropositive. These came from 7 different flocks in the eastern part of Norway, and were all adult sheep. In each of the positive flocks 1 or more animals
Table 1. Prevalence of animals with positive titres in the hemolysis inhibition test.

\begin{tabular}{llcc}
\hline Flocks & & $\begin{array}{c}\text { Number of } \\
\text { anınals } \\
\text { examıned }\end{array}$ & $\begin{array}{c}\text { Percentage } \\
\text { (number) of } \\
\text { positıve } \\
\text { anımals }\end{array}$ \\
\hline 1. & (Asker (NVH)) & 13 & $85(11)$ \\
2. & (Kongsberg) & 9 & $78(7)$ \\
3. & (Bærums værk) & 67 & $70(47)$ \\
4. & (Kjellerholen) & 22 & $36(8)$ \\
5. & (Âs (NLH)) & 50 & $24(12)$ \\
6. & (Alvdal) & 11 & $18(2)$ \\
7. & (Kongsberg) & 24 & $8(2)$ \\
$8-30$. & & $843^{*}$ & $0(0)$ \\
\hline
\end{tabular}

*) The number of anımals examıned in each of these flocks varied from 6 to 116 .

had high titres, indicating that none of these flocks were false positives. The titres varied from 0.6 to 3.3 in the flock with the highest range values. The prevalence of seropositive animals in the individual flocks varied from 8 to $85 \%$ (Table 1). Seropositive animals represented 3 breeds; dala, ryggja and spæl. In the present study, examinations of the animals for clinical lesions were not carried out. However, clinical cases of caseous lymphadenitis were reported in 1 flock (Bærums verk). In another flock (NLH) the disease is common in goats on the same farm.

The present study indicates that $C$ pseudotuberculosis infection does indeed occur in sheep flocks in Norway. More comprehensive investigations, including clinical and post mortem examinations, should, how- 
ever, be carried out to further clarify the prevalence and distribution of caseous lymphadenitis in Norwegian sheep flocks.

\section{Acknowledgement}

We thank Johan Krogsrud and Trude Bakke for providing sera for the investigation.

\section{$J$ K N. Kurla and G Holstad}

Department of Microbiology and Immunology,

Norwegian College of Veterınary Medıcıne,

Oslo, Norway and

Department of Veterinary Pathology and

Microbıology, Faculty of Veterinary Medicıne,

Unıversity of Narrobi, Kenya.

\section{References}

Addo PB, Eld FIA Caseous lymphadenitis of sheep and goats in Nigeria. Bull anim. Hith. Prod. Afr. 1978, 26, 37-41.

Ayers $J L$ Caseous lymphadenitis in goats and sheep: A review of diagnosis, pathogenesis, and immunity. J. Amer. vet. med. Ass. 1977, 171, 1251-1254.

Holstad $G$ Corynebacterium pseudotuberculosis infection in goats II. The prevalence of caseous lymphadenitıs in 36 goat herds in northern Norway. Acta vet. scand. 1986a, 27, 584-597.

Holstad $G$ Corynebacterium pseudotuberculosis infection in goats I. Evaluation of two serological diagnostic tests. Acta vet. scand. 1986b, 27, 575-583.

Jubb KVF, Kennedy PC Pathology of Domestic Animals. 2nd ed., Academic Press, New York 1970, 1, pp. 373-375.

Lovell $R$ Corynebacterial diseases. In: Stableforth AW \& Galloway EIA (eds.) Infectious Diseases of Animals. Vol. 2., Butterworths, London 1959, pp. 248-251.

Marsh $H$ Newsom's Sheep Diseases. 3rd ed., Williams \& Wilkins, Baltımore 1965, pp. 8790.

Turner $L W$ A review of the diagnosis of caseous lymphadenitis. Proc. 77th Ann. Meet. U.S. anim. Hlth. Ass. 1973, pp. 650-656.

(Receved October 5, 1988, accepted February 13, 1989)

Reprints may be requested from: Gudmund Holstad, Department of Microbiology and Immunology, Norwegian College of Veterınary Medicıne, P. O. Box 8146, Oslo Dep., N-0033 Oslo 1, Norway. 